\title{
Combining Vascularization Strategies in Tissue Engineering: The Faster Road to Success?
}

\author{
Thomas Später*, Emmanuel Ampofo, Michael D. Menger and Matthias W. Laschke \\ Institute for Clinical and Experimental Surgery, Saarland University, Homburg, Germany
}

Keywords: vascularization, microvascular fragments, arteriovenous loop, tissue engineering, blood vessels

\section{INTRODUCTION}

Tissue engineering is an interdisciplinary field of biomedical research that aims for the restoration of tissue defects or even the replacement of complete organs (Griffith and Naughton, 2002). For this purpose, tissue constructs are generated by seeding stem cells or tissue-specific cells on three-dimensional biomaterials, also referred to as scaffolds. These materials should mimic the natural extracellular matrix to ideally support the physiological function and regenerative capacity of the seeded cells (Hutmacher et al., 2004; Hutmacher and Cool, 2007). Moreover, they should

Edited by:

Wei Tan,

University of Colorado Boulder

United States

Reviewed by: Geraldine Mitchell,

University of Melbourne, Australia

${ }^{*}$ Correspondence:

Thomas Später

thomas.spaeter@uks.eu

Specialty section:

This article was submitted to

Tissue Engineering and Regenerative

Medicine,

a section of the journal Frontiers in Bioengineering and

Biotechnology

Received: 06 August 2020 Accepted: 20 November 2020 Published: 08 December 2020

Citation:

Später T, Ampofo E, Menger MD and Laschke MW (2020) Combining Vascularization Strategies in Tissue Engineering: The Faster Road to

Success?

Front. Bioeng. Biotechnol. 8:592095. doi: 10.3389/fbioe.2020.592095 rapidly vascularize to guarantee sufficient oxygen supply and, hence, cellular survival after their implantation into a tissue defect (Blinder et al., 2015; Cerino et al., 2017). In fact, the lack of an adequate vascularization is a major reason for the failure of particularly extensive and complex materials for the treatment of large-scale tissue defects (Maggi et al., 2003; Kneser et al., 2006; Leibig et al., 2016; Weigand et al., 2018; Yuan et al., 2018).

A promising strategy to overcome this problem is the generation of pre-vascularized tissue by means of an arteriovenous (AV) loop. This approach has not only demonstrated promising results in various experimental studies (Lokmic et al., 2007, 2008; Beier et al., 2009; Arkudas et al., 2013; Weigand et al., 2018), but is also already applied in clinical practice (Wang and Chu, 1996; Asif et al., 2005; Laschke and Menger, 2016; Henn et al., 2019; Hernández-Enríquez et al., 2019; McEwan et al., 2019). The basic concept of this in situ strategy is the generation of an axially vascularized tissue using the patient's own body as a bioreactor (Reichenberger et al., 2010; Laschke and Menger, 2016; Radwan et al., 2018; Weigand et al., 2018). In detail, an anastomosis between an artery and vein results in an AV loop, which is subsequently transferred into an enclosed implantation chamber to provide an isolated in vivo environment (Figure 1A) (Mian et al., 2000; Lokmic et al., 2008). This chamber is either empty or contains a cell-free or cell-seeded scaffold that needs to be vascularized (Mian et al., 2000; Lokmic et al., 2008; Weigand et al., 2016). During the following time course, mechanical shear stress stimulates the angiogenic sprouting of new microvessels out of the AV loop, which ultimately leads to the filling of the chamber with fibrovascular tissue (Figure 1A) (Asano et al., 2005; Dong et al., 2012; Zhan et al., 2016). Once the tissue inside the chamber is fully vascularized, it can be removed together with the AV loop and transferred to a tissue defect of the same patient. The main advantage of this procedure is the fact that the generated tissue can be transplanted with its AV loop and fully developed vascular network and, thus, easily anastomosed to the local blood vessels at the final site of implantation (Weigand et al., 2018).

However, although multiple animal studies have demonstrated the successful formation of angiogenic sprouts within AV loop-containing chambers over time (Asano et al., 2005; Kneser et al., 2006; Dong et al., 2012), their complete vascularization may take up to 12 weeks (Mian et al., 2000). 


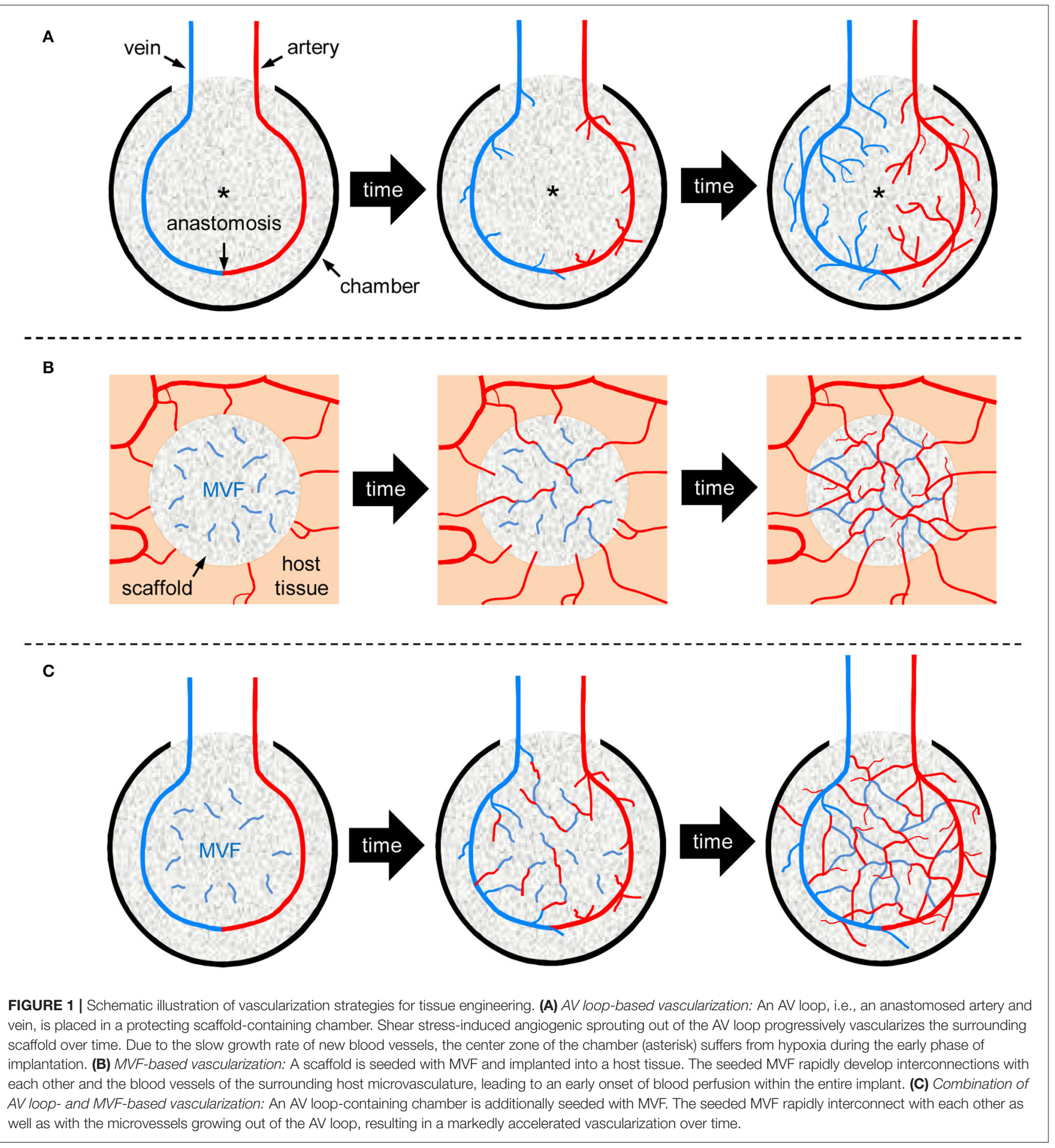

These findings indicate that AV loop-based vascularization is a rather time-consuming strategy, which therefore can be associated with a long hospitalization for patients.

To accelerate angiogenesis originating from AV loops, it has been suggested to use matrices as release systems for growth factors, such as vascular endothelial growth factor (VEGF) or basic fibroblast growth factor (bFGF) (Leibig et al., 2016). However, although growth factors stimulate angiogenic sprouting from pre-existing blood vessels, they can only accelerate the physiological growth rate of blood vessels, which is described to be only $\sim 5 \mu \mathrm{m} / \mathrm{h}$ (Utzinger et al., 2015), to a certain extent. On the other hand, Matsuda et al. (2013) 
suggested the use of stem cells to promote angiogenesis within the tissue of AV loop-containing chambers. They found that, most likely due to the initial hypoxic conditions within the chambers, only a few stem cells survived and were successfully incorporated into the newly formed tissue (Matsuda et al., 2013). Hence, there is an urgent need for the establishment of more effective strategies to accelerate tissue vascularization around AV loops. To achieve this, we herein suggest the novel approach of combining AV loop-based vascularization with another effective vascularization strategy, i.e., the transplantation of adipose tissue-derived microvascular fragments (MVF).

\section{MVF AS NATURAL VASCULARIZATION UNITS}

MVF represent a randomized mixture of biologically intact arteriolar, capillary and venular vessel segments, which can be rapidly isolated in large amounts from adipose tissue by means of mechanical dissection and enzymatic digestion (Frueh et al., 2017). They exhibit an intact vessel morphology with a central lumen, endothelial cells and stabilizing mural cells, such as pericytes (Laschke and Menger, 2015). Hence, they reassemble into new microvascular networks much faster than single cells and also develop interconnections to the surrounding host tissue after transplantation (Figure 1B) (Später et al., 2018). Moreover, their length of up to $150 \mu \mathrm{m}$ allows them to bridge relatively wide distances within seeded matrices (Später et al., 2017a). Finally, MVF also secrete various pro-angiogenic growth factors and are a rich source of mesenchymal stem cells and endothelial progenitor cells (McDaniel et al., 2014; Laschke and Menger, 2016). Accordingly, MVF have already been shown to be effective natural vascularization units for random pattern-flaps (Nakano et al., 1998), superficial myocardium (Nakano et al., 1999), epicardial patches (Shepherd et al., 2007), volumetric muscle defects (Pilia et al., 2014), pancreatic encapsulating devices (Hiscox et al., 2008) as well as scaffolds for bone and skin tissue engineering (Laschke et al., 2012; Später et al., 2017b, 2020).

Based on these findings, it is obvious that MVF may also significantly accelerate the vascularization within an AV loop-containing chamber. It may be speculated that, under future clinical conditions, MVF are rapidly isolated from liposuctioned fat of patients and seeded on an appropriate scaffold during the time of surgical AV loop creation. Both components could then be transferred in the AV loop chamber in an intra-operative one-step procedure. During the following course, the seeded MVF would rapidly interconnect with each other as well as with the microvessels growing out of the AV loop (Figure 1C). This would markedly reduce the time required for a sufficient vascularization of the entire chamber.

\section{PROOF OF CONCEPT AND CLINICAL TRANSLATION}

To analyze this approach under experimental conditions, we suggest to first perform animal studies in rats. In comparison to mice, the blood vessels in rats are larger and, thus, more suitable for anastomoses during the creation of AV loops. For this reason, the AV loop-technique has originally been established in rats (Korber and Flye, 1987) and since then been further developed in this species (Tanaka et al., 2000; Kneser et al., 2006; Arkudas et al., 2013; Schmidt et al., 2013). Furthermore, rats exhibit relatively large epididymal fat pads, which represent an ideal source for the isolation of sufficient amounts of MVF (Sato et al., 1987; Hoying et al., 1996).

In addition, it will be necessary to prove that the tissue within MVF/AV loop-containing chambers rapidly exhibits a functional blood perfusion, allowing its transfer to a defect site. For this purpose, several techniques have already been shown to be suitable. These include the intra-arterial injection of ink following chamber explantation (Bach et al., 2006; Kneser et al., 2006), microcomputed tomography (Arkudas et al., 2013) and sequential non-invasive magnetic resonance imaging (Hiscox et al., 2008).

Finally, the combination of MVF with AV loops should be evaluated in larger animal models, such as the pig or the sheep. These allow the creation of large-scale tissue defects that are comparable to those in humans (Morrison et al., 2016). However, before such studies can be conducted, the minimum number of MVF required to successfully pre-vascularize matrices used to surround AV-loops has yet to be determined. Once this parameter is evaluated, a rapid and sufficient vascularization of such particularly larger defects, which is of crucial importance for the successful translation of our suggested concept into clinical practice, may be possible.

\section{CONCLUSION}

Particularly for clinical applications, the creation of an AV loop currently represents one of the most promising vascularization strategies in tissue engineering due to the opportunity of surgically anastomosing a pre-vascularized tissue construct with the blood vessels at a defect site. However, AV loop-based vascularization is a time-consuming process, which basically underlies the kinetics of sprouting angiogenesis. This problem may be overcome by the use of MVF. Their isolation and autologous transfer into AV loop-containing chambers may be feasible in an intra-operative one-step procedure and may markedly accelerate and improve the subsequent prevascularization of an $\mathrm{AV}$ loop-connected tissue construct, resulting in a significantly reduced hospitalization of patients. Hence, the herein introduced concept of combining two efficient vascularization strategies may pave the way for a broad application of AV loop-based tissue engineering in future clinical practice.

\section{AUTHOR CONTRIBUTIONS}

TS and ML drafted the manuscript. EA attended the conceptual discussion of the paper. MM performed a critical review of the manuscript. All authors contributed to the article and approved the submitted version. 


\section{REFERENCES}

Arkudas, A., Balzer, A., Buehrer, G., Arnold, I., Hoppe, A., Detsch, R., et al. (2013). Evaluation of angiogenesis of bioactive glass in the arteriovenous loop model. Tissue Eng. Part C Methods. 19, 479-486. doi: 10.1089/ten.tec.2012.0572

Asano, Y., Ichioka, S., Shibata, M., Ando, J., and Nakatsuka, T. (2005). Sprouting from arteriovenous shunt vessels with increased blood flow. Med. Biol. Eng. Comput. 43, 126-130. doi: 10.1007/BF02345133

Asif, A., Gadalean, F. N., Merrill, D., Cherla, G., Cipleu, C. D., Epstein, D. L., et al. (2005). Inflow stenosis in arteriovenous fistulas and grafts: a multicenter, prospective study. Kidney Int. 67, 1986-1992. doi: 10.1111/j.1523-1755.2005.00299.x

Bach, A. D., Arkudas, A., Tjiawi, J., Polykandriotis, E., Kneser, U., Horch, R. E., et al. (2006). A new approach to tissue engineering of vascularized skeletal muscle. J. Cell. Mol. Med. 10, 716-726. doi: 10.1111/j.1582-4934.2006.tb00431.x

Beier, J. P., Horch, R. E., Arkudas, A., Polykandriotis, E., Bleiziffer, O., Adamek, E., et al. (2009). De novo generation of axially vascularized tissue in a large animal model. Microsurgery 29, 42-51. doi: 10.1002/micr.20564

Blinder, Y. J., Freiman, A., Raindel, N., Mooney, D. J., and Levenberg, S. (2015). Vasculogenic dynamics in 3D engineered tissue constructs. Sci. Rep. 5:17840. doi: $10.1038 /$ srep 17840

Cerino, G., Gaudiello, E., Muraro, M. G., Eckstein, F., Martin, I., Scherberich, A., et al. (2017). Engineering of an angiogenic niche by perfusion culture of adipose-derived stromal vascular fraction cells. Sci. Rep. 7:14252. doi: 10.1038/s41598-017-13882-3

Dong, Q. S., Shang, H. T., Wu, W., Chen, F. L., Zhang, J. R., Guo, J. P., et al. (2012). Prefabrication of axial vascularized tissue engineering coral bone by an arteriovenous loop: a better model. Mater. Sci. Eng. C Mater. Biol. Appl. 32, 1536-1541. doi: 10.1016/j.msec.2012.04.039

Frueh, F. S., Später, T., Lindenblatt, N., Calcagni, M., Giovanoli, P., Scheuer, C., et al. (2017). Adipose tissue-derived microvascular fragments improve vascularization, lymphangiogenesis, and integration of dermal skin substitutes. J. Invest. Dermatol. 137, 217-227. doi: 10.1016/j.jid.2016.08.010

Griffith, L. G., and Naughton, G. (2002). Tissue engineering-current challenges and expanding opportunities. Science 295, 1009-1014. doi: $10.1126 /$ science. 1069210

Henn, D., Wähmann, M. S. T., Horsch, M., Hetjens, S., Kremer, T., Gazyakan, E., et al. (2019). One-stage versus two-stage arteriovenous loop reconstructions: an experience on 103 cases from a single center. Plast. Reconstr. Surg. 143, 912-924. doi: 10.1097/PRS.0000000000005386

Hernández-Enríquez, M., Jiménez-Brítez, G., Leal-Bohorquez, N., SalazarMendiguchía, J., Brugaletta, S., Regueiro, A., et al. (2019). Use of an arteriovenous loop to facilitate transcatheter aortic valve alignment in a patient with giant ascending aortic aneurysm. JACC Cardiovasc. Interv. 12, 1863-1864. doi: 10.1016/j.jcin.2019.05.031

Hiscox, A. M., Stone, A. L., Limesand, S., Hoying, J. B., and Williams, S. K. (2008). An islet-stabilizing implant constructed using a preformed vasculature. Tissue Eng. A 14, 433-440. doi: 10.1089/tea.2007.0099

Hoying, J. B., Boswell, C. A., and Williams, S. K. (1996). Angiogenic potential of microvessel fragments established in three-dimensional collagen gels in vitro cell. Dev. Biol. Anim. 32, 409-419. doi: 10.1007/BF02723003

Hutmacher, D. W., and Cool, S. (2007). Concepts of scaffold-based tissue engineering - the rationale to use solid free-form fabrication techniques. J. Cell. Mol. Med. 11, 654-669. doi: 10.1111/j.1582-4934.2007.00078.x

Hutmacher, D. W., Sittinger, M., and Risbud, M. V. (2004). Scaffoldbased tissue engineering: rationale for computer-aided design and solid free-form fabrication systems. Trends Biotechnol. 22, 354-362. doi: 10.1016/j.tibtech.2004.05.005

Kneser, U., Polykandriotis, E., Ohnolz, J., Heidner, K., Grabinger, L., Euler, S., et al. (2006). Engineering of vascularized transplantable bone tissues: induction of axial vascularization in an osteoconductive matrix using an arteriovenous loop. Tissue Eng. 12, 1721-1731. doi: 10.1089/ten.2006.12. 1721

Korber, K. E., and Flye, M. W. (1987). Arteriovenous shunt construction for vascular access in the rat. Microsurgery 8, 245-246. doi: $10.1002 /$ micr.1920080415

Laschke, M. W., Kleer, S., Scheuer, C., Schuler, S., Garcia, P., Eglin, D., et al. (2012). Vascularisation of porous scaffolds is improved by incorporation of adipose tissue-derived microvascular fragments. Eur. Cell. Mater 24, 266-277. doi: 10.22203/eCM.v024a19

Laschke, M. W., and Menger, M. D. (2015). Adipose tissue-derived microvascular fragments: natural vascularization units for regenerative medicine. Trends Biotechnol. 33, 442-448. doi: 10.1016/j.tibtech.2015.06.001

Laschke, M. W., and Menger, M. D. (2016). Prevascularization in tissue engineering: current concepts and future directions. Biotechnol. Adv. 34, 112-121. doi: 10.1016/j.biotechadv.2015.12.004

Leibig, N., Wietbrock, J. O., Bigdeli, A. K., Horch, R. E., Kremer, T., Kneser, U., et al. (2016). Flow-induced axial vascularization: the arteriovenous loop in angiogenesis and tissue engineering. Plast. Reconstr. Surg. 138, 825-835. doi: 10.1097/PRS.0000000000002554

Lokmic, Z., Stillaert, F., Morrison, W. A., Thompson, E. W., and Mitchell, G. M. (2007). An arteriovenous loop in a protected space generates a permanent, highly vascular, tissue-engineered construct. FASEB J. 21, 511-522. doi: 10.1096/fj.06-6614com

Lokmic, Z., Thomas, J. L., Morrison, W. A., Thompson, E. W., and Mitchell, G. M. (2008). An endogenously deposited fibrin scaffold determines construct size in the surgically created arteriovenous loop chamber model of tissue engineering. J. Vasc. Surg. 48, 974-985. doi: 10.1016/j.jvs.2008.05.021

Maggi, S. P., Lowe, J. B. III., and Mackinnon, S. E. (2003). Pathophysiology of nerve injury. Clin. Plast. Surg. 30, 109-126. doi: 10.1016/S0094-1298(02)00101-3

Matsuda, K., Falkenberg, K. J., Woods, A. A., Choi, Y. S., Morrison, W. A., and Dilley, R. J. (2013). Adipose-derived stem cells promote angiogenesis and tissue formation for in vivo tissue engineering. Tissue Eng. A 19, 1327-1335. doi: 10.1089/ten.tea.2012.0391

McDaniel, J. S., Pilia, M., Ward, C. L., Pollot, B. E., and Rathbone, C. R. (2014). Characterization and multilineage potential of cells derived from isolated microvascular fragments. J. Surg. Res. 192, 214-222. doi: 10.1016/j.jss.2014.05.047

McEwan, S. J., Maple, H., and Gibbs, P. J. (2019). Good long-term patency: 10year follow-up using the mid-thigh adductor loop arteriovenous graft. J. Vasc. Access. 20, 313-320. doi: 10.1177/1129729818805955

Mian, R., Morrison, W. A., Hurley, J. V., Penington, A. J., Romeo, R., Tanaka, Y., et al. (2000). Formation of new tissue from an arteriovenous loop in the absence of added extracellular matrix. Tissue Eng. 6, 595-603. doi: 10.1089/10763270050199541

Morrison, W. A., Marre, D., Grinsell, D., Batty, A., Trost, N., and O'Connor, A. J. (2016). Creation of a large adipose tissue construct in humans using a tissueengineering chamber: a step forward in the clinical application of soft tissue engineering. EBioMedicine 6, 238-245. doi: 10.1016/j.ebiom.2016.03.032

Nakano, M., Nakajima, Y., Kudo, S., Tsuchida, Y., Nakamura, H., and Fukuda, O. (1998). Effect of autotransplantation of microvessel fragments on experimental random-pattern flaps in the rat. Eur. Surg. Res. 30, 149-160. doi: $10.1159 / 000008571$

Nakano, M., Nakajima, Y., Kudo, S., Tsuchida, Y., Nakamura, H., and Fukuda, O. (1999). Successful autotransplantation of microvessel fragments into the rat heart. Eur. Surg. Res. 31, 240-248. doi: 10.1159/000008699

Pilia, M., McDaniel, J. S., Guda, T., Chen, X. K., Rhoads, R. P., Allen, R. E., et al. (2014). Transplantation and perfusion of microvascular fragments in a rodent model of volumetric muscle loss injury. Eur. Cell. Mater. 28, 11-23. doi: 10.22203/eCM.v028a02

Radwan, M. S., Barakat, A. Z., Jaber, M. M., and Mashal, A. A. (2018). Free flap transfer with arteriovenous loop establishment for upper limb salvage in a crush injury. Plast Reconstr. Surg. Glob. Open 6:e1913. doi: 10.1097/GOX.0000000000001913

Reichenberger, M. A., Harenberg, P. S., Pelzer, M., Gazyakan, E., Ryssel, H., Germann, G., et al. (2010). Arteriovenous loops in microsurgical free tissue transfer in reconstruction of central sternal defects. J. Thorac. Cardiovasc. Surg. 140, 1283-1287. doi: 10.1016/j.jtcvs.2010.05.019

Sato, N., Sawasaki, Y., Senoo, A., Fuse, Y., Hirano, Y., and Goto, T. (1987). Development of capillary networks from rat microvascular fragments in vitro: the role of myofibroblastic cells. Microvasc. Res. 33, 194-210. doi: 10.1016/0026-2862(87)90017-3

Schmidt, V. J., Hilgert, J. G., Covi, J. M., Weis, C., Wietbrock, J. O., de Wit, C., et al. (2013). High flow conditions increase connexin 43 expression in a rat arteriovenous and angioinductive loop model. PLoS ONE 8:e78782. doi: 10.1371 /journal.pone. 0078782 
Shepherd, B. R., Hoying, J. B., and Williams, S. K. (2007). Microvascular transplantation after acute myocardial infarction. Tissue Eng. 13, 2871-2879. doi: 10.1089/ten.2007.0025

Später, T., Frueh, F. S., Menger, M. D., and Laschke, M. W. (2017a). Potentials and limitations of Integra $($ ) flowable wound matrix seeded with adipose tissue-derived microvascular fragments. Eur. Cell. Mater. 33, 268-278. doi: 10.22203/eCM.v033a20

Später, T., Frueh, F. S., Nickels, R. M., Menger, M. D., and Laschke, M. W. (2018). Prevascularization of collagen-glycosaminoglycan scaffolds: stromal vascular fraction versus adipose tissue-derived microvascular fragments. J. Biol. Eng. 12:24. doi: 10.1186/s13036-018-0118-3

Später, T., Körbel, C., Frueh, F. S., Nickels, R. M., Menger, M. D., and Laschke, M. W. (2017b). Seeding density is a crucial determinant for the in vivo vascularisation capacity of adipose tissue-derived microvascular fragments. Eur. Cell. Mater. 34, 55-69. doi: 10.22203/eCM.v034a04

Später, T., Tobias, A. L., Menger, M. M., Nickels, R. M., Menger, M. D., and Laschke, M. W. (2020). Biological coating with platelet-rich plasma and adipose tissue-derived microvascular fragments improves the vascularization, biocompatibility and tissue incorporation of porous polyethylene. Acta Biomater. 108, 194-206. doi: 10.1016/j.actbio.2020.03.018

Tanaka, Y., Tsutsumi, A., Crowe, D. M., Tajima, S., and Morrison, W. A. (2000). Generation of an autologous tissue (matrix) flap by combining an arteriovenous shunt loop with artificial skin in rats: preliminary report. Br. J. Plast. Surg. 53, 51-57. doi: 10.1054/bjps.1999. 3186

Utzinger, U., Baggett, B., Weiss, J. A., Hoying, J. B., and Edgar, L. T. (2015). Large-scale time series microscopy of neovessel growth during angiogenesis. Angiogenesis 18, 219-232. doi: 10.1007/s10456-015-9 461-x
Wang, S. S., and Chu, S. H. (1996). Clinical use of omniflow vascular graft as arteriovenous bridging graft for hemodialysis. Artif. Organs. 20, 1278-1281. doi: 10.1111/j.1525-1594.1996.tb00674.x

Weigand, A., Beier, J. P., Arkudas, A., Al-Abboodi, M., Polykandriotis, E., Horch, R. E., et al. (2016). The Arteriovenous (AV) loop in a small animal model to study angiogenesis and vascularized tissue engineering. J. Vis. Exp. 117:54676. doi: $10.3791 / 54676$

Weigand, A., Horch, R. E., Boos, A. M., Beier, J. P., and Arkudas, A. (2018). The arteriovenous loop: engineering of axially vascularized tissue. Eur. Surg. Res. 59, 286-299. doi: 10.1159/000492417

Yuan, Q., Arkudas, A., Horch, R. E., Hammon, M., Bleiziffer, O., Uder, M., et al. (2018). Vascularization of the arteriovenous loop in a rat isolation chamber model-quantification of hypoxia and evaluation of its effects. Tissue Eng. A 24, 719-728. doi: 10.1089/ten.tea.2017.0262

Zhan, W., Marre, D., Mitchell, G. M., Morrison, W. A., and Lim, S. Y. (2016). Tissue engineering by intrinsic vascularization in an in vivo tissue engineering chamber. J. Vis. Exp. 111:54099. doi: 10.3791/54099

Conflict of Interest: The authors declare that the research was conducted in the absence of any commercial or financial relationships that could be construed as a potential conflict of interest.

Copyright (c) 2020 Später, Ampofo, Menger and Laschke. This is an open-access article distributed under the terms of the Creative Commons Attribution License (CC $B Y)$. The use, distribution or reproduction in other forums is permitted, provided the original author(s) and the copyright owner(s) are credited and that the original publication in this journal is cited, in accordance with accepted academic practice. No use, distribution or reproduction is permitted which does not comply with these terms. 